Ekawaty Rante Liling, Firmanto Adi Nurcahyo, Karin Lucia Tanojo

\title{
HUBUNGAN ANTARA KECERDASAN SPIRITUAL DENGAN PROKRASTINASI PADA MAHASISWA TINGKAT AKHIR
}

\author{
Ekawaty Rante Liling, Firmanto Adi Nurcahyo, Karin Lucia Tanojo \\ Fakultas Psikologi Universitas Pelita Harapan Surabaya \\ Jl. A.Yani 288 Surabaya 60234 \\ ranteliling.ekawaty@gmail.com, firmanto.adi@uphsurabaya.ac.id, \\ karin.lucia@uphsurabaya.ac.id.
}

\begin{abstract}
Procrastination can occur to university students especially in finishing final papers. Procrastination is a behavior detrimental to oneself and others that associate with lack of ability to manage themselves. The ability of self-management is part of how someone judges and values every actions and that involve spiritual intelligence. This study examines the relationship between spiritual intelligence and procrastination behavior of students who do the final paper. This research involved 62 students at the Universitas Pelita Harapan Surabaya. Spiritual intelligence scale and procrastination scale were used to collect the data. Results show there is a significant negative correlation between spiritual intelligence and procrastination ( $\mathrm{r}=$ $-0.307, \mathrm{p}=0.008, \mathrm{p}<0.01)$. The higher spiritual intelligence level, the lower procrastination behavior will be and vice versa. Spiritual intelligence would lead someone to decide on appropriate actions and think about the consequences of his/her actions. Students who have high spiritual intelligence would tend to avoid procrastination behavior that disserving themselves and others.
\end{abstract}

Keywords: final paper; procrastination;spiritual intelligence

\begin{abstract}
Abstrak
Prokrastinasi dapat terjadi di kalangan mahasiswa khususnya dalam pengerjaan tugas akhir, dimana hal ini seringkali dipengaruhi oleh kurangnya kemampuan untuk menetapkan aturan bagi diri sendiri. Kemampuan untuk mengatur diri sendiri tidak terlepas dari bagaimana seseorang menilai dan memaknai setiap tindakannya, dan hal ini berkaitan dengan kecerdasan
\end{abstract}


spiritual. Penelitian ini bertujuan untuk mengetahui apakah ada hubungan antara kecerdasan spiritual dengan prokrastinasi pada mahasiswa tingkat akhir. Subjek dalam penelitian ini adalah 62 mahasiswa Universitas Pelita Harapan Surabaya yang sedang mengerjakan tugas akhir. Kecerdasan spiritual diukur dengan menggunakan skala kecerdasan spiritual dan prokrastinasi diukur menggunakan skala prokrastinasi yang diadaptasi dari Tuckman Procrastination Scale (TPS). Hasil uji korelasi menunjukkan adanya hubungan negatif yang sangat signifikan antara kecerdasan spiritual dengan prokrastinasi pada subjek penelitian $(r=-0,307, p=0,008, p<$ $0,01)$. Semakin tinggi kecerdasan spiritual mahasiswa, semakin rendah prokrastinasinya dan sebaliknya. Kecerdasan spiritual akan menuntun seseorang untuk memutuskan tindakan yang tepat dan memikirkan dampak yang akan ditimbulkan oleh tindakannya. Mahasiswa yang memiliki kecerdasan spiritual yang tinggi akan cenderung menghindari prokrastinasi karena perilaku tersebut merugikan dirinya sendiri maupun orang lain.

Kata kunci: kecerdasan spiritual; prokrastinasi; tugas akhir

\section{Pendahuluan}

Perguruan Tinggi merupakan salah satu lembaga pendidikan yang keberadaannya bertujuan untuk mendukung terwujudnya tujuan pendidikan nasional (Badan Standar Nasional Pendidikan, 2010). Hasil dari perguruan tinggi adalah para mahasiswa yang akan mengambil peran menurut bidang keahliannya masing-masing. Para mahasiswa inilah yang diharapkan dapat menjadi generasi penerus dan tulang punggung dalam pembangunan bangsa. Salah satu syarat untuk menyelesaikan studi dan untuk memperoleh gelar sarjana di perguruan tinggi adalah mahasiswa harus menyelesaikan mata kuliah tugas akhir (Poerwodarminto dalam Fibrianti, 2009). Tugas akhir merupakan sarana pengukur kemampuan akademik secara integratif atas dasar alur penalaran analisis dan sistematis sesuai bidang peminatan ilmu yang ditekuni (Universitas Pelita Harapan Surabaya, 2008). Pengerjaan tugas akhir pada umumnya membutuhkan waktu sekitar satu semester atau kurang lebih enam bulan, namun pada kenyataannya banyak mahasiswa yang membutuhkan waktu lebih dari satu semester untuk menyelesaikan tugas akhirnya.

Mahasiswa yang merasa tidak berdaya untuk menghadapi hambatan dalam pengerjaan skripsinya atau tugas akhirnya, akan berusaha untuk menghindar dari pengerjaan tugas akhir tersebut atau melakukan penundaan dalam pengerjaan tugas 
akhirnya (Kingofong, 2004). Penundaan dalam mengerjakan tugas akhir ini perlu menjadi poin penting untuk diperhatikan karena tugas akhir tidak hanya menunjukkan kualitas produk sarjana tetapi juga menunjukkan kualitas proses belajar-mengajar yang ada di dalamnya. Penelitian dalam beberapa tahun terakhir ini menunjukkan bahwa perilaku menunda adalah masalah yang umumnya terjadi di dunia akademis (LaForge dalam Gunawinata, 2008).

Prokrastinasi pada dasarnya memiliki pengertian menunda tugas atau tindakan. Prokastinasi berasal dari bahasa Latin, yaitu pro, yang berarti mendorong atau ke depan, dan crastinus, yang berarti keputusan hari esok. Gabungan kedua kata ini, prokrastinasi berarti menunda atau menangguhkan hingga hari esok (Steel, 2007). Definisi prokstinasi secara umum dipahami sebagai hal yang dilakukan secara sadar. Gafni dan Geri (2010) mendefinisikan prokrastinasi sebagai kecenderungan yang berada di bawah kontrol seseorang untuk menunda aktivitas hingga detik-detik terakhir, atau tidak melakukannya sama sekali.

Tuckman (1990), salah satu ahli yang mengembangkan alat ukur prokrastinasi, membahas perilaku prokrastinasi dari tiga aspek yakni (a) gambaran diri secara umum mengenai kecenderungan untuk menunda suatu tugas tertentu, aspek ini merujuk pada gambaran seseorang mengenai kebiasaan dan kecenderungannya untuk menunda melakukan ataupun menyelesaikan pengerjaan suatu tugas; (b) kecenderungan untuk memiliki kesulitan melakukan hal-hal yang tidak menyenangkan, dan ketika memungkinkan akan menghindari atau mencari jalan keluar dari hal tersebut, aspek ini merujuk kepada kecenderungan untuk menyerah ketika menemui tugas yang sulit dan kecenderungan untuk memilih kesenangan yang mudah diperoleh; dan (c) kecenderungan untuk menyalahkan orang lain akan keadaan sulityang dialami, dimana aspek ini berfokus pada kecenderungan untuk menghindarkan tanggung jawab dari diri sendiri dan menyalahkan orang lain. Kecenderungan ini dapat dilihat dari berbagai hal, seperti kepercayaan bahwa orang lain tidak berhak memberikan batas waktu kepada individu dalam mengerjakan sesuatu.

Penelitian yang telah dilakukan sehubungan dengan prokrastinasi menemukan adanya korelasi yang sangat erat antara perilaku prokrastinasi dengan menurunnya performa akademis (Akinsola, Tella, \& Tella, 2007), juga mengakibatkan rendahnya kepuasan hidup (Özer \& Saçkes, 2011) dan kesejahteraan seseorang (Steel, 2007). Prokrastinasi juga terbukti sebagai perilaku yang merugikan secara finansial, terutama ketika seseorang menunda dalam membayar pajak (Kasper, 2004), ataupun menunda pengerjaan tugas akhir masa akademik (Prastyo, 2011).

Prokrastinasi yang ditunjukkan seringkali diasosiasikan dengan kurangnya 
kemampuan untuk mengatur diri (regulasi diri). Penelitian telah memverifikasi bahwa prokrastinasi dari seseorang seringkali dipengaruhi oleh kurangnya kemampuan untuk menetapkan aturan bagi dirinya sendiri dan menjalankannya (Vahedi, Mostatafi, \& Mortazanajad, 2009). Seseorang yang melakukan prokrastinasi cenderung berencana untuk melakukannya, namun pada akhirnya tidak mampu untuk memenuhi rencana tersebut. Dengan kata lain, ia belum mampu untuk memenuhi tuntutannya sendiri dan belum mampu bertanggung jawab dengan dirinya sendiri.

Kemampuan untuk mengatur diri sendiri atau bertanggung jawab terhadap diri sendiri, terkait dengan bagaimana seseorang menilai dan memaknai setiap tindakannya (Alwisol, 2006). Kemampuan untuk menilai makna tindakan dan makna hidup ini, berkaitan erat dengan kecerdasan spiritual yang oleh Zohar dan Marshall (dalam Sitepu, 2007) disebutkan sebagai kecerdasan individu untuk menilai makna dari tindakan yang dilakukannya. Menurut Zohar dan Marshall (2000) kecerdasan spiritual adalah kecerdasan untuk menghadapi dan memecahkan persoalan makna dan nilai, kecerdasan untuk menempatkan perilaku dan hidup dalam konteks makna yang lebih luas dan kaya, serta kecerdasan untuk menilai bahwa tindakan atau jalan hidup seseorang lebih bermakna dibandingkan dengan orang lain.

Zohar dan Marshall (2000) mengungkapkan bahwa kecerdasan spiritual terdiri dari dimensi-dimensi sebagai berikut: (a) kemampuan bersikap fleksibel yaitu dapat menempatkan diri dan menerima pendapat orang lain secara terbuka; (b) tingkat kesadaran yang tinggi seperti kemampuan autocritism dan mengerti tujuan serta visi hidupnya; (c) kemampuan untuk menghadapi dan memanfaatkan hal-hal yang menyulitkan yang ditandai dengan tidak adanya penyesalan, tetap tersenyum, dan bersikap tenang; (d) kemampuan menghadapi dan menyembuhkan rasa sakit yang ditandai dengan munculnya sikap ikhlas dan pemaaf; (e) kualitas hidup yang diilhami oleh visi dan nilai-nilai seperti prinsip dan pegangan hidup dan berpijak pada kebenaran; (f) keengganan untuk menyebabkan kerugian yang tidak perlu misalnya menunda pekerjaan dan cenderung untuk berpikir sebelum bertindak; (g) kecenderungan melihat keterkaitan antara berbagai hal atau memiliki pandangan yang holistik yakni mampu untuk berpikir secara logis dan berlaku sesuai dengan norma sosial; (h) kecenderung menanyakan “mengapa” atau "bagaimana” jika akan mencari jawaban-jawaban yang mendasar dan memiliki kemampuan untuk berimajinasi, serta memiliki rasa ingin tahu yang tinggi; (i) mudah untuk bekerja melawan konvensi (adat dan kebiasaan sosial), seperti mau memberi dan tidak mau menerima.

Kecerdasan spiritual akan menolong seseorang untuk dapat memutuskan mana yang baik dan yang tidak baik, serta dapat memikirkan kemungkinan yang akan 
terjadi, dan punya cita-cita untuk terus memperbaiki dirinya (Zohar dan Marshall, 2000). Prokrastinasi merupakan salah satu bentuk perilaku yang dapat membawa pada akibat-akibat negatif yang merugikan. Seorang mahasiswa yang memiliki kecerdasan spiritual yang tinggi akan mampu memikirkan setiap kemungkinan akibat dari tindakan-tindakannya sehingga ia akan menghindari tindakan-tindakan yang dapat merugikan dirinya sendiri maupun orang lain. Hal ini salah satunya terwujud dengan mengerjakan tugas tepat waktu.

Berdasarkan telaah terhadap hasil-hasil penelitian terdahulu di atas, peneliti menemukan bahwa belum banyaknya penelitian yang mengkaji prokrastinasi dari segi kecerdasan individu, padahal kecerdasan juga merupakan faktor penting yang membentuk perilaku seseorang (Hidayat, 2007). Oleh karena itu penelitian ini bertujuan untuk mengetahui hubungan antara kecerdasan spiritual dengan prokrastinasi pada mahasiswa tingkat akhir di Universitas Pelita Harapan Surabaya. Hipotesis yang diajukan dalam penelitian ini adalah ada hubungan yang negatif antara kecerdasan spiritual dengan prokrastinasi pada mahasiswa tingkat akhir di Universitas Pelita Harapan Surabaya.

\section{Metode Penelitian}

Subjek dalam penelitian ini adalah 62 mahasiswa dari enam jurusan yang ada di Universitas Pelita Harapan Surabaya serta terdiri dari laki-laki dan perempuan. Pemilihan subjek dalam penelitian ini, menggunakan metode purposive sampling atau pemilihan berdasarkan kriteria, yakni mahasiswa tingkat akhir yang sedang mengerjakan tugas akhirnya. Data untuk subjek yang memenuhi kriteria tersebut diperoleh dari bagian Tata Usaha Universitas Pelita Harapan Surabaya.

Karakteristik subjek diamati berdasarkan data demografis yaitu jurusan dan jenis kelamin, yang diperoleh melalui data diri yang diisi subjek pada kuesioner yang diberikan. Jumlah subjek paling banyak adalah mahasiswa dari program studi Psikologi sejumlah 17 orang atau 27\% dari keseluruhan subjek penelitian, kedua adalah mahasiswa dari program studi Akuntansi yakni 16 subjek atau 26\%, disusul Manajemen yaitu 15 subjek (25\%), Sistem Informasi yakni 8 subjek (13\%), dan Teknik Industri dan Hukum yang masing-masing 3 mahasiswa atau 5\% dari keseluruhan subjek penelitian. Berdasarkan jenis kelamin, subjek dalam penelitian ini didominasi oleh perempuan yakni sejumlah 37 atau 59,7\% dari jumlah keseluruhan subjek penelitian, sedangkan laki-laki hanya 25 atau 40,3\%.

Penelitian ini dimulai dengan mempersiapkan alat ukur yang digunakan. Tahap 
selanjutnya penelitimenghubungi pihak universitas untukmengajukan permohonan untuk pengambilan data. Peneliti kemudian menghubungi pihak Tata Usaha untuk mendapat data tentang mahasiswa yang sedang mengerjakan tugas akhir dan menghubungi mahasiswa yang sedang mengerjakan tugas akhir tersebut untuk memperoleh alamat email maupun nomor telpon mereka yang dapat dihubungi karena tidak semua mahasiswa yang sedang mengerjakan tugas akhir tersebut dapat ditemui secara langsung di kampus. Langkah selanjutnya adalah peneliti melakukan uji coba instrumen, kemudian melakukan analisis terhadap instrumen yang telah diujicobakan berdasarkan reliabilitas instrumen dan daya beda masing-masing butir dalam instrumenyang ada. Revisi instrumen pun dilakukan berdasarkan hasil analisis tersebut. Setelah proses revisi butir selesai, maka peneliti melakukan pengumpulan data dengan alat ukur atau instrumen yang telah disiapkan tersebut. Data yang telah dikumpulkan kemudian diolah dalam rangka uji hipotesis dan untuk mencapai kesimpulan dari penelitian ini.

Alat ukur pada penelitian ini diujicobakan pada mahasiswa yang memiliki karakteristik yang sama dengan subjek penelitian yaitu mahasiswa yang sedang mengerjakan tugas akhir di Universitas Pelita Harapan Surabaya. Uji coba instrumen tersebut dilakukan dengan membagikan kuesioner yang telah disiapkan kepada 34 mahasiswa Universitas Pelita Harapan Surabaya yang sedang mengerjakan tugas akhir. Penyebaran dari subjek uji coba berdasarkan program studi adalah 9 mahasiswa Psikologi, 9 mahasiswa Akuntansi, 8 mahasiswa Manajemen, 2 mahasiswa Teknik Industri, 5 mahasiswa Sistem Informasi, 1 mahasiswa Hukum.

Instrumen atau alat ukur yang digunakan dalam penelitian ini untuk mengukur variabel penelitian adalah kuesioner, baik untuk prokrastinasi maupun kecerdasan spiritual.

\section{Prokrastinasi}

Dalam penelitian ini, prokrastinasi diukur dengan menggunakan skala yang diadaptasi dari Tuckman Procrastination Scale (TPS). TPS ini dikembangkan oleh Tuckman (1990) dan terdiri dari 35 butir. Skala ini diterjemahkan terlebih dahulu ke dalam bahasa Indonesia oleh peneliti sebelum digunakan untuk mengumpulkan data. Skala terjemahan tersebut diperlihatkan kepada pakar dalam bahasa Inggris untuk diperiksa ketepatan terjemahannya. Untuk masingmasing butir terdapat empat pilihat jawaban, yaitu "ini menggambarkan diri saya”, "saya cenderung melakukan ini”, "saya cenderung tidak melakukan ini”, dan "ini tidak menggambarkan diri saya”. Tabel 1 menunjukkan contoh item pada masingmasing aspek prokrastinasi. 
Tabel 1. Contoh item Prokrastinasi

\begin{tabular}{ll}
\hline \multicolumn{1}{c}{ Aspek } & \multicolumn{1}{c}{ Item } \\
\hline $\begin{array}{l}\text { Deskripsi umum mengenai } \\
\text { kecenderungan menunda } \\
\text { sesuatu }\end{array}$ & $\begin{array}{l}\text { Saya menunda menyelesaikan suatu } \\
\text { pekerjaan, meskipun pekerjaan tersebut } \\
\text { penting.Saya berjanji pada diri saya untuk } \\
\text { segera melakukan sesuatu, tetapi } \\
\text { kemudian menundanya juga. }\end{array}$ \\
$\begin{array}{l}\text { Kecenderungan menghindari } \\
\text { tugas yang sulit atau tidak } \\
\text { menyenangkan }\end{array}$ & $\begin{array}{l}\text { Saya menunda memulai suatu hal yang } \\
\text { sulit.Ketika saya merasa terhambat, saya } \\
\text { berhenti mengerjakan tugas saya. }\end{array}$ \\
$\begin{array}{l}\text { menyalahkan orang lain akan } \\
\text { situasi yang dihadapi }\end{array}$ & $\begin{array}{l}\text { Saya menganggap bahwa orang yang } \\
\text { memberi saya pekerjaan yang sulit adalah } \\
\text { orang yang tidak adil.Orang lain tidak } \\
\text { berhak untuk memberikan saya deadline }\end{array}$ \\
\hline
\end{tabular}

Seleksi item dilakukan dengan mempertahankan item dengan daya beda $>0.3$ (Azwar, 2009). Berdasarkan hal tersebut, jumlah butir skala prokrastinasi yang diperoleh dari seleksi item adalah 21 butir dengan persebaran pada tiap aspek seperti dalam tabel 2. Untuk aspek ketiga yakni kecenderungan untuk menyalahkan orang lain akan situasi yang dihadapi, proporsi 2 item dipertahankan sesui dengan prosentase pada skala TPS dimana aspek ini memiliki prosentase sebesar $10 \%$ dari total item.

Tabel 2. Susunan butir skala prokrastinasi untuk pengambilan data

\begin{tabular}{|c|c|c|c|c|}
\hline \multirow{2}{*}{\multicolumn{2}{|c|}{ No. Aspek }} & \multicolumn{2}{|c|}{ Nomor butir } & \multirow{3}{*}{$\begin{array}{c}\text { Jumlah } \\
13\end{array}$} \\
\hline & & \multirow{2}{*}{$\begin{array}{l}\text { Favorable } \\
1,3,5,11,14, \\
16,8,13\end{array}$} & \multirow{2}{*}{$\begin{array}{l}\text { Unfavorable } \\
8,7,17,19,21\end{array}$} & \\
\hline 1 & $\begin{array}{l}\text { Deskripsi umum mengenai } \\
\text { kecenderungan menunda } \\
\text { sesuatu }\end{array}$ & & & \\
\hline 2 & $\begin{array}{l}\mathrm{K} \text { e c e } \mathrm{n} \text { d e } \mathrm{r} \text { u } \mathrm{n} \mathrm{g} \text { a } \mathrm{n} \\
\text { menghindari tugas yang sulit } \\
\text { atau tidak menyenangkan }\end{array}$ & $2,6,4,20,15$ & 10 & 6 \\
\hline \multirow[t]{2}{*}{3} & $\begin{array}{l}\text { Kecenderungan untuk } \\
\text { menyalahkan orang lain } \\
\text { akan situasi yang dihadapi }\end{array}$ & 9,12 & - & 2 \\
\hline & Jumlah & 15 & 6 & 21 \\
\hline
\end{tabular}


Uji reliabilitas skala prokrastinasi menunjukkan bahwa setelah dilakukan seleksi item, nilai Cronbach's Alpha yang ditunjukkan adalah 0,882. Estimasi reliabilitas ini menjadi lebih tinggi jika dibandingkan dengan reliabilitas sebelum dilakukannya seleksi item yakni sebesar 0.823 . Reliabilitas dari sebuah skala makin sempurna jika koefisien reliabilitasnya makin mendekati satu (Azwar, 2004).

\section{Kecerdasan Spiritual}

Kecerdasan spiritual dalam penelitian ini diukur dengan menggunakan skala kecerdasan spiritual yang disusun sendiri oleh peneliti berdasarkan dimensi dan indikator kecerdasan spiritual yang dikemukakan oleh Zohar dan Marshall (2000). Peneliti lalu meminta pendapat dari pakar dalam bidang pendidikan. Hal ini dilakukan untuk menegakkan validitas isi melalui professional judgment. Sejumlah 45 item dihasilkan pada proses ini. Tabel 4 menunjukkan contoh item pada masing-masing aspek kecerdasan spiritual.

Tabel 4. Contoh item Kecerdasan Spiritual

\begin{tabular}{|c|c|}
\hline Aspek & Item \\
\hline Bersikap Fleksibel & Saya senang menerima masukan dari orang lain \\
\hline Kesadaran Diri & $\begin{array}{l}\text { Saya tahu dengan jelas tentang apa yang akan } \\
\text { saya kerjakan di masa depan }\end{array}$ \\
\hline $\begin{array}{l}\text { Menghadapi dan } \\
\text { memanfaatkan penderitaan }\end{array}$ & $\begin{array}{l}\text { Saya tetap semangat menjalani hidup saya } \\
\text { meskipun menghadapi suatu masalah }\end{array}$ \\
\hline $\begin{array}{l}\text { Menghadapi dan melampaui } \\
\text { perasaan sakit }\end{array}$ & $\begin{array}{l}\text { Saya ikhlas menerima permintaan maaf orang } \\
\text { lain }\end{array}$ \\
\hline $\begin{array}{l}\text { Keengganan untuk } \\
\text { menyebabkan kerugian }\end{array}$ & $\begin{array}{l}\text { Saya selalu mempertimbangkan apa yang akan } \\
\text { saya lakukan sebelum benar-benar } \\
\text { melakukannya }\end{array}$ \\
\hline Kualitas hidup & $\begin{array}{l}\text { Saya memiliki prinsip bahwa hidup itu harus } \\
\text { berpijak pada kebenaran }\end{array}$ \\
\hline Berpandangan holistik & $\begin{array}{l}\text { Saya memilih untuk hidup berdasarkan norma } \\
\text { dan ajaran agama saya }\end{array}$ \\
\hline Kecenderungan bertanya & $\begin{array}{l}\text { Saya senang bertanya dan mencari tahu tentang } \\
\text { hal yang saya anggap penting. }\end{array}$ \\
\hline Bidang Mandiri & $\begin{array}{l}\text { Saya terbiasa menyelesaikan masalah saya } \\
\text { sendiri }\end{array}$ \\
\hline
\end{tabular}


Hasil seleksi item dengan mempertahankan item dengan daya beda $>0.3$ menghasilkan 21 item yang terseleksi dengan persebaran pada tiap aspek seperti terlihat dalam tabel 5. Uji reliabilitas skala kecerdasan spiritual setelah seleksi item menunjukkan nilai Cronbach’s Alpha sebesar 0,816. Estimasi reliabilitas ini menjadi lebih tinggi jika dibandingkan dengan reliabilitas sebelum dilakukannya seleksi item yakni sebesar 0.691 .

Tabel 5. Susunan butir skala kecerdasan spiritual untuk pengambilan data

\begin{tabular}{llccc}
\hline \multirow{2}{*}{ No. Aspek } & \multicolumn{2}{c}{ Nomor butir } & \\
\cline { 2 - 4 } & Favorable & Unfavorable & Jumlah \\
\hline 1 & Bersikap Fleksibel & 1,11 & - & 2 \\
2 & $\begin{array}{l}\text { Kesadaran diri } \\
3\end{array}$ & 5 & 18 & 2 \\
& $\begin{array}{l}\text { Menghadapi } \\
\text { memanfaatkan penderitaan }\end{array}$ & 13,15 & - & 2 \\
4 & $\begin{array}{l}\text { Menghadapi dan melampaui } \\
\text { perasaan sakit }\end{array}$ & 20 & 6 & 2 \\
5 & $\begin{array}{l}\text { Keengganan untuk } \\
\text { menyebabkan kerugian }\end{array}$ & 9 & & \\
6 & $\begin{array}{l}\text { Kualitas hidup } \\
7\end{array}$ & 2,16 & 14 & 2 \\
8 & $\begin{array}{l}\text { Berpandangan holistik } \\
\text { Kecenderungan bertanya }\end{array}$ & 12 & 8,16 & 4 \\
9 & Bidang Mandiri & 21,19 & 17 & 2 \\
\hline & Jumlah & 14 & 7 & 21 \\
\hline
\end{tabular}

Setelah keseluruhan data yang dibutuhkan telah terkumpul, maka peneliti melakukan uji asumsi yang meliputi uji normalitas dan uji linearitas. Uji normalitas dilakukan dengan menggunakan tes normalitas yakni kolmogorov-Smirnov, sedangkan scatterplot digunakan untuk menguji linearitas kedua variabel. Setelah uji asumsi, peneliti melakukan uji hipotesis dengan menggunakan korelasi Pearson Product Moment. Proses analisis data dilakukan dengan menggunakan program SPSS 16.0 for Windows.

\section{Hasil dan Pembahasan}

Hasil uji normalitas variabel kecerdasan spiritual dan prokrastinasi menunjukkan nilai signifikansi kolmogorov-smirnov sebesar 0,200 ( $>>0,05)$. Hal ini menunjukkan 
bahwa data kecerdasan spiritual dan prokrastinasi dalam penelitian ini memiliki distribusi normal. Hasil uji linearitas dalam penelitian ini menunjukkan bahwa sebaran nilai-nilai variabel berada di sekitar garis lurus atau mengikuti garis linear.

Hasil analisis korelasi menunjukkan bahwa koefisien korelasi Pearson untuk variabel kecerdasan spiritual dan prokrastinasi adalah sebesar-0,307. Angka korelasi sebesar yakni $r=-0,307$ dengan nilai signifikansi sebesar 0,008 $(\mathrm{p}<0,01)$, menunjukkan adanya korelasi atau hubungan yang sangat signifikan antara variabel kecerdasan spiritual dengan variabel prokrastinasi.

Nilai r yang negatif menunjukkan adanya korelasi yang negatif antara kecerdasan spiritual dengan prokrastinasi. Hal ini berarti, semakin tinggi kecerdasan spiritual mahasiswa maka prokrastinasinya akan semakin rendah, begitu pula sebaliknya, jika prokrastinasi semakin tinggi, maka kecerdasan spiritual akan semakin rendah. Berdasarkan hasil uji korelasi di atas, maka dapat disimpulkan bahwa hipotesis dalam penelitian ini dapat diterima yaitu terdapat hubungan yang negatif antara kecerdasan spiritual dengan prokrastinasi pada mahasiswa tingkat akhir di Universitas Pelita Harapan Surabaya.

Hasil penelitian tersebut dapat dijelaskan dengan beberapa hal berikut. Kecerdasan spiritual seseorang akan mendorongnya untuk memiliki kesadaran diri dan menilai makna dibalik segala macam tindakannya (Zohar dan Marshall, 2000). Zohar dan Marshall (2000) juga mengemukakan bahwa kecerdasan spiritual dapat menuntun seseorang untuk memutuskan tindakan yang tepat dan memikirkan dampak yang akan ditimbulkan oleh tindakannya. Oleh karena itu, besar kemungkinan bagi mahasiswa yang memiliki kecerdasan spiritual yang tinggi untuk menghindari prokrastinasi karena perilaku ini merupakan tindakan yang merugikan baik bagi dirinya sendiri maupun bagi orang lain.

Prokrastinasi terkait erat dengan perasaan tidak berdaya dalam menghadapi tantangan atau tugas yang dianggap sulit, yang menyebabkan seseorang menghindari tugas tersebut atau melakukan penundaan (Kingofong, 2004). Dengan kata lain, prokrastinasi akan muncul karena adanya kecenderungan untuk menghindari mengerjakan tugas-tugas yang sulit dan berupaya mencari hal menyenangkan yang mudah diperolehnya (Tuckman, 1990), namun seseorang yang memiliki kecerdasan spiritual yang tinggi akan memiliki kemampuan untuk menghadapi hal-hal yang menyulitkan bahkan mampu memanfaatkan situasi menyulitkan tersebut untuk terus berjuang (Zohar dan Marshall, 2000). Oleh karena itu, seseorang yang memiliki kecerdasan spiritual yang tinggi akan terus berjuang mengerjakan dan menyelesaikan tugas yang dianggap sulit sehingga kecil kemungkinan untuk melakukan penundaan 
pada tugas tersebut.

Prokrastinasi tidak hanya terkait dengan sikap menghindar dari tugas tersebut tetapi juga ada kecenderungan untuk menyalahkan orang lain atas keadaan sulit atau tugas sulit yang dihadapinya (Tuckman, 1990). Di sisi lain, seseorang yang memiliki kecerdasan spiritual yang tinggi juga memiliki kesadaran diri yang tinggi dan memiliki kemampuan untuk mengevaluasi dirinya sendiri (autocritism) atas apa yang dilakukannya dan mempertimbangkan konsekuensi dari tindakannya (Zohar dan Marshall, 2000). Oleh karena itu, seseorang yang memiliki kecerdasan spiritual yang tinggi kemungkinan besar akan mampu menyadari kekeliruannya dan memperbaiki tindakannya sendiri tanpa menyalahkan orang lain.

Para peneliti telah berusaha menemukan faktor-faktor yang menyebabkan terjadinya prokrastinasi atau faktor yang berkontribusi pada terjadinya perilaku prokrastinasi. Beberapa penelitian berfokus pada faktor karakteristik tugas yang dilakukan, seperti tingkat kesulitan dan imbalan yang diperoleh, sementara yang lain berfokus pada kondisi demografis subjek, seperti usia dan jenis kelamin (Steel, 2007). Sementara itu, peneliti yang lain memilih berfokus pada faktor-faktor seperti kepercayaan diri dan ketakutan akan kegagalan (Solomon \& Rothblum, 1984), selfefficacy (Yao, 2009), regulasi diri (Vahedi, Mostafafi, \& Mortazanajad, 2009), conscientiousness (Scher \& Osterman, 2002), perfeksionisme (Yao, 2009), ataupun manajemen waktu (Hussain \& Sultan, 2010).

Hasil penelitian Klassen dkk. (2010) menunjukkan adanya keterkaitan antar variabel prokrastinasi, prestasi akademik, dan variabel-variabel motivasi. Hasil uji hubungan menunjukkan bahwa prokrastinasi memiliki korelasi sebesar -0.21 dengan prestasi akademik (IPK), $\mathrm{r}=-0.15$ dengan self efficacy, dan $\mathrm{r}=-0.23$ dengan self esteem. Jika dibandingkan dengan hasil penelitian tersebut, hasil penelitian ini memberikan gambaran hubungan yang lebih kuat antara prokrastinasi dengan kecerdasan spiritual yang ditunjukkan dengan korelasi sebesar -0.307. Dengan kata lain dalam hal ini kecerdasan spiritual dimungkinkan menjadi prediktor yang cukup kuat terhadap prokrastinasi dibandingkan dengan variabel yang lain.

Beberapa kelemahan menjadi keterbatasan dalam penelitian ini. Peneliti dalam hal ini hanya menggunakan satu cara pengumpulan data yaitu penyebaran kuesioner, sedangkan dalam penelitian sosial penggunaan kuesioner, memiliki resiko yang besar untuk menimbulkan sosial desirability bias, apalagi jika penelitian yang berkaitan dengan hal-hal yang normatif. Oleh karena itu, penelitian selanjutnya disarankan untuk menambahkan pendekatan lain seperti obervasi dan wawancara. Selain itu, penelitian ini hanya berfokus pada mahasiswa di Universitas Pelita Harapan Surabaya dimana 
universitas ini cukup menekankan muatan pengembangan iman dan karakter dalam kurikulum pada setiap program studinya. Oleh karena itu peneliti selanjutnya diharapkan dapat mengambil subjek dari universitas lain yang memiliki kurikulum berbeda sehingga hasilnya dapat diperbandingkan.

\section{Simpulan}

Berdasarkan hasil uji korelasi dalam penelitian ini, dapat disimpulkan bahwa terdapat hubungan yang negatif antara kecerdasan spiritual dan perilaku menunda pada mahasiswa tingkat akhir di UPHS. Dengan kata lain, semakin tinggi kecerdasan spiritual, maka perilaku menunda akan semakin rendah. Hal sebaliknya, jika perilaku menunda semakin tinggi maka kecerdasan spiritual akan semakin rendah. Hal ini didukung oleh pendapat Zohar dan Marshall (2000) yang menyatakan bahwa kecerdasan spiritual akan menolong seseorang untuk memutuskan tindakan yang tepat dan memikirkan dampak yang akan ditimbulkan oleh tindakannya. Oleh karena itu, besar kemungkinan bagi mahasiswa yang memiliki kecerdasan spiritual yang tinggi untuk menghindari perilaku menunda. Sebagai penelitian yang dilakukan dalam lingkup pendidikan maka implikasi penelitian ini diharapkan dapat memperluas wawasan dalam dunia pendidikan mengenai pentingnya kecerdasan spiritual dalam mendukung proses penyelesaian studi mahasiswa. Penelitian ini juga menambah wawasan bahwa kecerdasan spiritual tidak hanya berkaitan dengan agama tetapi juga berkaitan dengan pemaknaan akan tindakan atau perilaku sehari-hari.

\section{Daftar Pustaka}

Akinsola, M. K., Tella, A., \& Tella, A. (2007). Correlates of academic procrastination and mathematics achievement of university undergraduate students. Eurasia Journal of Mathematics, Science \& Technology Education, 3 (4), 363370 .

Alwisol. (2006). Psikologi kepribadian, edisi revisi. Malang: UMM Press

Azwar, S. (2004). Reliabilitas dan validitas. Yogyakarta: Pustaka Pelajar

Azwar, S. (2009). Metode penelitian. Yogyakarta: Pustaka Pelajar

Badan Standar Nasional Pendidikan. (2010). Laporan BSNP. Jakarta: Tim Penulis Badan Standar Nasional Pendidikan. 
Ekawaty Rante Liling, Firmanto Adi Nurcahyo, Karin Lucia Tanojo

Fibriati, I.D. (2009). Hubungan antara dukungan sosial orang tua dengan prokrastinasi akademik dalam menyelesaikan skripsi pada mahasiswa fakultas psikologi universitas diponegoro. (Skripsi). Semarang: Universitas Diponegoro

Gafni, R., \& Geri, N. (2010). Time management: Procrastination tendency in individual and collaborative task. Interdisciplinary Journal of Information, Knowledge, and Management, 5, 115-125.

Gunawinata, V.A.R. (2008). Perfeksionis, prokrastinasi akademik, dan penyelesaian skripsi mahasiswa. Anima, Indonesian Psychological Journal, Vol. 23 no.3, 256-276. Surabaya: Universitas Surabaya.

Hidayat, A.F. (2007). Hubungan antara kecerdasan spiritual dengan motivasi belajar melalui optimisme masa depan pada siswa smp n 2 jenawi (Tesis). Surakarta: Universitas Muhammadiyah

Hussain, I., \& Sultan, S. (2010). Analysis of procrastination among university students. Procedia Social and Behavioral Sciences, 5, 1897-1904

Jahja, Y. (2011). Psikologi perkembangan. Jakarta: Kencana

Kasper, G. (30 Maret 2004). Tax procrastination: Survey finds 29\% have yet to begin taxes. Diunduh tanggal 27 Maret 2011, dari http://www.prweb.com/ releases/2004/3/prweb114250.html

Kingofong, S.M. (2004). Penghambat pada pengerjaan skripsi. Skripsi, tidak diterbitkan. Fakultas Psikologi Universitas Surabaya.

Klassen, R.M, Ang, R.B, Chong, W.H, Krawchuck, L.L, Huan, V.S, Wong, I.Y.F, Yeo, L.S. (2010). Academic Procrastination in two settings: Motivation correlates, behavioral patterns, and negative impact of procrastination in Canada and Singapore. Applied Psychology: An International Review, 59 (3), 361-379.

Özer, B. U., \& Saçkes, M. (2011). Effects of academic procrastination on college students' life satisfaction. Procedia Social and Behavioral Sciences, 12, 512-519.

Prastyo, E. (13 Maret 2011). Orang Indonesia suka menunda-nunda pekerjaan. Diunduh tanggal 27 Maret 2011, dari http://kelanakota.suarasurabaya.net/ ?id=c00af6deea14970466dce2e23ff7781b201190037. 
Scher, S. J., \& Osterman, N. M. (2002). Procrastination, conscientiousness, anxiety, and goals: Exploring the measurement and correlates of procrastination among school-aged children. Psychology in The School, 39 (4), 385398.

Sitepu, N. (2007). Hubungan antara kecerdasan spiritual dengan kecenderungan depresi pada remaja. Skripsi, tidak diterbitkan, Fakultas Psikologi Universitas Surabaya.

Solomon, L. J., \& Rothblum, E. D. (1984). Academic procrastination: Frequency and cognitive-behavioral correlates. Journal of Counseling Psychology, 31 (4), 503-509.

Steel, P. (2007). The Nature of procrastination: A meta-analytic and theoretical review of quintessential self-regulatory failure. Psychological Bulletin, 133 (1), 65-94.

Tuckman, B. W. (1990). Measuring procrastination attitudinally and behaviorally. Diunduh dari ERIC database. (ED319792)

Universitas Pelita Harapan Surabaya. (2008). Keputusan rektor dalam bidang akademik. Surabaya: Tim Penulis Universitas Pelita Harapan Surabaya.

Vahedi, S., Mostafafi, F., \& Mortazanajad, H. (2009). Self-regulation and dimensions of parenting styles predict psychological procrastination of undergraduate students. Iran Journal of Psychiatry, 4, 147-154.

Yao, M. P. (2009). An Exploration of multidimensional perfectionism, academic self-efficacy, procrastination frequency, and asian american cultural values in asian american university students (Disertasi doktoral). Diunduh dari http://etd.ohiolink.edu/

Zohar, D. \& Marshall, I. (2000). SQ: Memanfaatkan kecerdasan spiritual dalam berpikir integralistik dan holistik untuk memaknai kehidupan, (Rahmani, Nadjib, Baiquni: alih bahasa). Bandung: Mizan. 